\title{
PAPP-A in Indian Water Buffalo (Bubalus bubalis) Ovary: Phylogeny, Expression, Hormonal Regulation, and Sequence Characterization
}

\author{
Varij Nayan · Anuradha Bhardwaj • \\ Dheer Singh
}

Received: 22 May 2012/ Accepted: 2 April 2013/Published online: 1 May 2013

(C) NAAS (National Academy of Agricultural Sciences) 2013

\begin{abstract}
The insulin-like growth factor binding proteins and pregnancy-associated plasma protein-A (PAPP-A) within the future dominant follicle is a critical part of selection of one follicle. This study was aimed to find out the expression and hormonal regulation of PAPP-A mRNAs in the Indian water buffalo ovary. The results showed stage-specific expression of PAPP-A in the whole follicles and postovulatory structures, corpus luteum and corpus albicans. Expression of PAPP-A mRNA was found to be up regulated in corpus luteum. The 341 nucleotide partial cDNA sequence of buffalo PAPP-A was determined. Sequence analyses have revealed that bubaline PAPP-A belongs to Zinc-metzincin superfamily (zincdependent metalloprotease) and pappalysin-like subfamily. It also confirmed the stimulatory effect of follicle-stimulating hormone on PAPP-A mRNA expression. The PAPP-A sequences showed more than $90 \%$ homology with reported sequences of cattle, sheep, pig, and human. The study was an attempt in understanding local regulatory mechanism of follicular selection and development in buffalo ovary.
\end{abstract}

Keywords Ovary $\cdot$ PAPP-A $\cdot$ IGFBPs $\cdot$ Bubalus bubalis $\cdot$ FSH

V. Nayan · A. Bhardwaj · D. Singh $(\bowtie)$

Molecular Endocrinology Laboratory, Division of Animal

Biochemistry, National Dairy Research Institute (ICAR),

Karnal 132001, Haryana, India

e-mail: drdheer.singh@gmail.com

V. Nayan

e-mail: varij.biochem@gmail.com

A. Bhardwaj

e-mail: dranu.biotech@gmail.com

Present Address:

V. Nayan

BPR Division, Central Institute for Research on Buffaloes

(ICAR), Sirsa Road, Hisar 125001, Haryana, India

Present Address:

A. Bhardwaj

Basic and Supporting Discipline Unit, National Research Centre

on Equines (ICAR), Sirsa Road, Hisar 125001, Haryana, India

\section{Introduction}

The ovary is a dynamic organ in respect to rapid and extensive degrees of tissue development and remodeling. Each follicle destined for ovulation must execute the development and differentiation of its components: the innermost oocyte and its nurse-cells: granulosa cells and theca cells [36]. The changes in ovary involving dramatic changes in granulosa cell function are sequential and are dictated by specific, regulated responses to gonadotropins, steroids, and growth factors [21, 39, 42].

Insulin-like growth factor-I (IGF-I) system is an important factor in follicular development. IGFBPs increase IGFs half life and maintain a stable pool of IGFs in many compartments of the organisms. However, the affinity of IGFBPs for IGF-I and IGF-II can be modulated by changes in local synthesis as well as their post translational modifications via proteolysis. Such proteolysis has been described in the serum of female rodents and humans during pregnancy after nutritional fasting, during severe illness or following extensive trauma and in culture 
medium of osteoblastic cells, granulosa cells, and tumor cells [30]. The protease that degrades IGFBP-3, 4, and 5 found in sheep follicular fluid (FF) has been identified a serine metalloprotease. The IGFBP protease in bovine and equine $\mathrm{FF}$ also has characteristics of a serine metalloprotease and was hypothesized to be pregnancy-associated plasma protein-A (PAPP-A). Such decrease in the affinity of IGFBPs for IGFs by increasing bioavailability of IGFs can lead to a potentiation rather than an inhibition of action of the ligands.

PAPP-A was originally isolated in 1974 , as one of four proteins of placental origin found circulating at high concentrations (at a level of $50 \mathrm{mg} / \mathrm{l}$ ) in pregnant women [29]. Lawrence and coworkers [28] isolated an IGF-dependent IGFBP-4 protease activity from human fibroblast conditioned media and identified it as PAPP-A. Subsequently, PAPP-A was also shown to be expressed by osteoblasts, vascular smooth muscle cells, and ovarian granulosa cells, as well as by placental trophoblasts in culture $[5,11,14,20]$. Clearly, PAPP-A could no longer be considered just "pregnancy associated." In vitro studies and the characterization of a PAPP-A knock-out mouse model suggested this IGFBP protease as an important regulator of local IGF bioavailability [13]. Placenta is the major site of PAPP-A synthesis; however, relatively high level of PAPP-A was found in ovarian FF as IGFBP-4 protease. Mature PAPP-A is secreted as a homodimer of approximately $400 \mathrm{kDa}$ composed of two $200 \mathrm{kDa}$ disulfide-bound subunits [37]. The observation that FF from healthy follicles had considerably higher levels of PAPP-A activity than did atretic follicles led to the hypothesis that PAPP-A expression may play a role in the dynamics of dominant follicle development. Experimentally, this concept was supported by in situ hybridization studies in which PAPP-A mRNA was identified in granulosa cells of healthy, but not atretic follicles [33]. PAPP-A is present in the FF of the future dominant follicles and the follicular selection may be result of series of changes beginning with the acquisition of PAPP-A, decrease in IGFBP-4 and -5 and increase in free IGF, which synergizes with FSH to increase estradiol production [17].

Amino acid sequences of PAPP-A orthologues show a remarkable conservation, which suggests an essential function of PAPP-A in a variety of mammalians. Amino acid sequence identity between human and mouse or human and rat PAPP-A approaches $91 \%$ [45]. In addition, incomplete sequences from other mammals reveal very few substitutions when compared to human PAPP-A [35]. PAPP-A is also present in non-mammalian vertebrates viz. Fugu rubripes, Tetraodon nigroviridis (60 and $50 \%$ conservation, respectively, with human PAPP-A), Danio rerio (zebrafish), and Xenopus laevis. In contrast, PAPP-A is not found in DNA sequence databases from invertebrates such as Drosophila melanogaster or Caenorhabditis elegans [8].
PAPP-A belongs to the metzincin superfamily of metalloproteinases [7] and now considered as the first member of a new metzincin family, the pappalysins. Mature PAPP-A monomer contains 1,547 amino acids representing the C-terminal part of the proform of PAPP-A [26]. Two structural motifs that define the unifying features in the primary structures of members of the metzincin superfamily of metalloproteinases, which include the matrixins (matrix metalloproteinases, MMPs), serralysins, astacins, and adamalysins (ADAMs), can be identified in PAPP-A $[9,48]$. The proteolytic domain contains an elongated zincbinding consensus sequence HEXXHXXGXXH and a Met-turn motif (M). In addition, three calcium binding Lin12-Notch (LNR) repeats are found in PAPP-A. The molecule of PAPP-A is distinct in several regards from other four members of metzincin superfamily of metalloproteinases. A putative $\mathrm{Zn}^{2+}$ binding site, which has been found in PAPP-A molecule, is very similar to that containing the active site $\mathrm{Zn}^{2+}$ of the matrix metalloproteinases and quite similar to these of other metalloproteinases [26]. It is interesting that in PAPP-A the linear distance between the zinc motif and the conserved Met residue is 63 amino acids, whereas in other metzincins this distance is shorter between 7 and 44 residues [48]. The proteolytic domain of $\sim 350$ amino acids is thought to be responsible for the ability of PAPP-A to cleave IGFBPs.

In view of the importance of PAPP-A and no information on expression in buffalo ovary, the present investigation was envisaged.

\section{Materials and Methods}

\section{Collection of Ovaries and Isolation of Whole Follicles}

Buffalo ovaries were obtained from nearby abattoirs and processed further as per our previous report [50]. Nonatretic follicles were grouped as small $(<5 \mathrm{~mm}$ diameter), medium (5-9 $\mathrm{mm}$ diameter), and large ( $>9 \mathrm{~mm}$ diameter) preovulatory and pooled according to their size representing different stages of follicular development [47]. Postovulatory structures, mid-luteal phase corpora lutea (CL) and corpus albicans (CA) were isolated and classified based on morphological appearance including size, extent of vascularity, presence and absence of central blood, and color and overall appearance of ovary.

\section{Granulosa Cell Isolation and Culture}

Granulosa cells were isolated from follicles as described by Malhotra et al. [32]. The granulosa cells in FF were aspirated from small, medium, and large antral follicles using $18 \mathrm{G}$ needle and syringe. The FF collected in $2.0 \mathrm{ml}$ 
eppendorf tube (for RNA isolation) or $15 \mathrm{ml}$ sterile centrifuge tubes (for cell culture) were centrifuged at $2,000 \mathrm{rpm}$ for $5 \mathrm{~min}$ to get pellet of cells for RNA isolation and cell culture.

Trypan blue staining was used for assessment of granulosa cell viability during follicle isolation and culture in vitro. Cell viability was estimated at $30-40 \%$ by counting in a hemacytometer. Approximately $8 \times 10^{6}$ viable granulosa cells were plated in a six-well culture plate (Costar Corporation, Cambridge, USA) using bicarbonate-buffered MEM with antibiotics (Plain media, $\mathrm{pH}$ 7.2) and $3 \%$ FBS (Sigma Chemical Co., USA, \# F7524) to permit cell anchorage. Cells were allowed to attach in culture dish for $24 \mathrm{~h}$ at $37{ }^{\circ} \mathrm{C}$ at $5 \% \mathrm{CO}_{2}$. Monolayer was maintained in about $2.0 \mathrm{ml}$ per well serum containing media in a water jacketed $\mathrm{CO}_{2}$ incubator (Nuaire, USA) for about 1 day. After $24 \mathrm{~h}$ of cell culturing in FBS, cells were observed under inverted microscope (Olympus CK2) for cell attachment and viability. FBS containing MEM was removed. The cells were washed with plain media. Different concentrations (5 and $100 \mathrm{ng} / \mathrm{ml}$ ) of ovine FSH (NIDDK-oFSH-17) were prepared in plain media. The cells were treated with FSH in a set of three wells for each concentration. For control, $2.0 \mathrm{ml}$ of plain media was added and the plates were kept for incubation at $5 \% \mathrm{CO}_{2}$ for a minimum period of $24 \mathrm{~h}$. After $24 \mathrm{~h}$ of treatment, cells were observed under microscope for growth and viability. Suspended media was removed and cells were further suspended in $2.0 \mathrm{ml}$ of TRI reagent.

\section{Isolation of Total RNA}

The total RNA was isolated from granulosa cells obtained from FF as well as culture, using TRI reagent (Molecular Research Centre, Inc \# TR-118). Granulosa cells grown in monolayer culture were lysed directly in culture dish with $1 \mathrm{ml}$ of TRI reagent $/ 10 \mathrm{~cm}^{2}$ of culture dish after removal of spent media. Luteal tissues (100 mg) were immersed in
$1 \mathrm{ml}$ of TRI reagent and homogenized. Similarly, intact 7-8 small, 3-4 medium, and 1-2 large size follicles were homogenized separately in $1 \mathrm{ml}$ of TRI reagent and processed further for RNA isolation. Total RNA with the ratio $\left(A_{260 / 280}\right)$ ranging from 1.8 to 2.0 were accepted for subsequent procedures. RNA was stored at $-70{ }^{\circ} \mathrm{C}$. Integrity of RNA preparation was evaluated by agarose $(1 \%)$ gel electrophoresis, after its denaturation with glyoxal and dimethylsulfoxide [43]. The RNA was treated with DNAfree $^{\mathrm{TM}}$ kit (Ambion Inc., USA, \# 1906) to remove contaminating DNA.

\section{Primer Design and Selection}

Primer sequences were designed online using the software Primer 3 Output Program (http://www.genome.wi.mit.edu). PCR primers were selected in such a way that the $5^{\prime}$ - and $3^{\prime}$ - primers span different exons. Primer sequences information and their expected amplification products are provided in Table 1. All oligonucleotides were commercially synthesized from Operon Biotechnologies $\mathrm{GmbH}$, Cologne, Germany.

\section{Reverse Transcriptase-Polymerase Chain Reaction}

Reverse transcriptase-polymerase chain reaction (RT-PCR) was performed using M-MuLV RT PCR Kit (Bangalore Genei Pvt. Ltd., Bangalore, India; \# KT74) in two steps viz. first strand cDNA synthesis (RT) reaction and PCR amplification. For first strand cDNA synthesis, $1 \mu \mathrm{g}$ of RNA sample was taken in a sterile DNA/RNA/DNase/ RNase/Pyrogen and PCR inhibitor-free microfuge tube (Labware Scientific Inc., \# PCR-02N) and diluted to $9.5 \mu \mathrm{l}$ with sterile water $\left(\mathrm{sH}_{2} \mathrm{O}\right)$. Then $0.5 \mu \mathrm{l}$ of random hexamers was added. The solution was incubated at $65{ }^{\circ} \mathrm{C}$ for $10 \mathrm{~min}$ in a thermocycler (Whatman Biometra, Germany) and reagents were added in the order: $1 \mu \mathrm{l}$ RNase inhibitor, $1 \mu \mathrm{LTT}(0.1 \mathrm{M}), 4 \mu \mathrm{l} 5 \times$ reverse transcriptase buffer,

Table 1 Primers used for amplification in PCR

\begin{tabular}{|c|c|c|c|c|c|c|}
\hline Gene name & $\begin{array}{l}\text { Primer } \\
\text { orientation }\end{array}$ & Sequence $\left(5^{\prime}-3^{\prime}\right)$ & $\begin{array}{l}\text { Length } \\
\text { (bp) }\end{array}$ & $\mathrm{GC}(\%)$ & $\operatorname{Tm}\left({ }^{\circ} \mathrm{C}\right)$ & $\begin{array}{l}\text { Amplification } \\
\text { product (bp) }\end{array}$ \\
\hline \multirow[t]{2}{*}{ PAPP-A (first design) } & Forward & CCAGCTCCGAAACACAAGTT & 20 & 50.0 & 60.4 & \multirow[t]{2}{*}{341} \\
\hline & Reverse & AATCTCCTTCCAGGCAAAG & 20 & 50.0 & 60.4 & \\
\hline \multirow[t]{2}{*}{ PAPP-A (second design) } & Forward & CATGTGGCTTCAACAGCTTC & 20 & 60.0 & 64.5 & \multirow[t]{2}{*}{300} \\
\hline & Reverse & GCACCAGGAATCTCCCTTC & 19 & 55.0 & 62.45 & \\
\hline \multirow[t]{2}{*}{$\beta$-Actin } & Forward & CGTGGGCCGCCTAGGCACCA & 21 & 47.6 & 53.2 & \multirow[t]{2}{*}{243} \\
\hline & Reverse & TTGGCCTTAGGGTTCAGGGGGG & 22 & 57.0 & 57.6 & \\
\hline \multirow[t]{2}{*}{ G3PDH } & Forward & AAACCCATCACCATCTTCCAG & 21 & 50.0 & 60.4 & \multirow[t]{2}{*}{367} \\
\hline & Reverse & AGGGGCCATCCACAGTCTTCT & 21 & 57.89 & 62.32 & \\
\hline
\end{tabular}

* An annealing temperature of $60^{\circ} \mathrm{C}$ was used during PCR 
$1 \mu \mathrm{dNTP} \operatorname{mix}(30 \mathrm{mM}), 1 \mu \mathrm{l}$ M-MuLV RT enzyme, and $\mathrm{sH}_{2} \mathrm{O}$ to bring the reaction volume to $20 \mu \mathrm{l}$. Furthermore, the reaction was set up at $37^{\circ} \mathrm{C}$ for $1 \mathrm{~h}, 95^{\circ} \mathrm{C}$ for $5 \mathrm{~min}$, and stopped at $4{ }^{\circ} \mathrm{C}$. For amplification of cDNA, the following PCR components were added to a DNA/RNA/ DNase/RNase/Pyrogen and PCR inhibitor-free microfuge tube: $2 \mu \mathrm{l}$ cDNA product, $5 \mu \mathrm{l} 10 \times$ assay buffer for Taq polymerase, $1 \mu \mathrm{l}$ dNTP $\operatorname{mix}(30 \mathrm{mM}), 1 \mu \mathrm{l}$ upstream primer $(10 \mu \mathrm{M}), 1 \mu \mathrm{l}$ downstream primer $(10 \mu \mathrm{M}), 1 \mu \mathrm{l}$ Taq polymerase enzyme $(1 \mathrm{U} / \mu \mathrm{l})$, and $\mathrm{sH}_{2} \mathrm{O}$ to bring the reaction volume to $50 \mu \mathrm{l}$. PCR reactions were performed in the thermocycler with cycle conditions: $94{ }^{\circ} \mathrm{C}$ for $2 \mathrm{~min}$, followed by 30 cycles of $94^{\circ} \mathrm{C}$ for $1 \mathrm{~min}$, annealing temperature $\left(60^{\circ} \mathrm{C}\right)$ for $1 \mathrm{~min}$ and $72{ }^{\circ} \mathrm{C}$ for $1 \mathrm{~min}$. A 4-min final extension at $72{ }^{\circ} \mathrm{C}$ was performed following last cycle and reaction was stopped at $4{ }^{\circ} \mathrm{C}$.

PCR conditions for the analysis of gene expression by semi-quantitative RT-PCR have been optimized as described earlier [32]. The experiment was repeated thrice with different RNA samples.

\section{Analysis of PCR Products}

PCR product $(7 \mu \mathrm{l})$ mixed with $1.4 \mu \mathrm{l}$ of $6 \times$ gel loading dye was loaded on agarose $(2 \%)$ gel and run in minisubmarine gel electrophoresis system with TBE buffer $(1 \times)$. The gel was stained with ethidium bromide $(0.5 \mu \mathrm{g} /$ $\mathrm{ml}$ ) and the amplified products were visualized on UVtransilluminator. Intensity of individual bands was measured by densitometry using GelQuant.NET software (from biochemlabsolutions.com).

\section{Gel Extraction and Sequencing of Purified PCR}

Products

Gel extraction of PCR products was done by Wizard ${ }^{\circledR} \mathrm{SV}$ Gel and PCR Clean-Up System (Promega, USA). After the gel extraction, the PCR products were custom sequenced (Sigma Genosys Lab., Bangalore).

\section{Statistical Analysis}

Densitometric analysis results were expressed as ratio obtained by dividing the band intensity of target gene (PAPP-A) with intensity of control gene (G3PDH or $\beta$ actin). The relative abundance of mRNA expression between different stages of ovarian cycle was done by one way analysis of variance (ANOVA) for three biological replicates and Microsoft Office Excel 2007. The values were compared at 5 and $1 \%$ level of probability. Differences were considered significant at $P<0.05$ and $P<0.01$.
In Silico Analysis of Nucleotide and Deduced Amino Acid Sequences

Additional mammalian sequences of PAPP-A were retrieved from NCBI GenBank as follows: cattle (XM_613511), sheep (AF421140), horse (XM_001487931), mouse (NM_021 362), rat (NM_001107939), human (X68280), rhesus monkey (XM_001095160), chimpanzee (XR_024483), Pig (XM_001926753), rabbit (XM_002720482), and giant panda (XM_002915787). Sequences were edited and analyzed using the BLAST and Clustal W programs. Multiple sequence alignments were produced by CLC Sequence Viewer 6.5.1. Secondary structure was predicted using PSIPREDv3.0 of the PSIPRED protein structure prediction web server at UCL department of computer science [10]. Amino acid or peptide sequences were deduced from their respective cDNA sequences and further multiple sequence alignments were done by MEGA 5.0 program [49]. Molecular phylogenetic analysis was performed from the data provided by the multiple sequence alignment patterns of amino acids following the Maximum-Likelihood method based on 1,000 bootstrap replications and Jones-TaylorThornton (JTT) matrix-based model [24] by the MEGA 5.0 program. Phosphorylation prediction was done by NetPhos 2.0 server of CBS, Technical University of Denmark [6]. CSS Palm 2.0 online server was used for finding potential palmitoylation sites [41]. Similarly, to predict glycation of $\varepsilon$ amino groups of lysines in the deduced peptide sequence, NetGlycate 1.0 server [23] and to predict the Leucine-rich nuclear export signals (NES), NetNES 1.1 server [27] of CBS, Technical University of Denmark was used. DiANNA 1.1 web server was used for finding cysteines and potential disulfide bonds [16].

\section{Results}

Expression of PAPP-A mRNA in Buffalo Ovary

The relative expression pattern of PAPP-A mRNA from whole follicles of different sizes, corpus luteum, and corpus albicans is shown in Fig. 1. Moderate PAPP-A mRNA expression was observed in small and large whole follicles as represented in lanes 2 and 4 of Fig. 1a, respectively. In medium sized follicles, PAPP-A mRNA expression was found to be down regulated (lane 3 ). The expression pattern of PAPP-A gene was found to be significantly $(P<0.05)$ high in corpus luteum (lane 5). Corpus albicans, on the other hand, showed less expression of PAPP-A mRNA. Similar expression pattern of PAPP-A mRNA was observed when glyceraldehyde 3-phosphate dehydrogenase was used as control gene along with PAPP-A (300 bp, different set of PAPP-A primers) (Fig. 1b). Figure 1c 
A

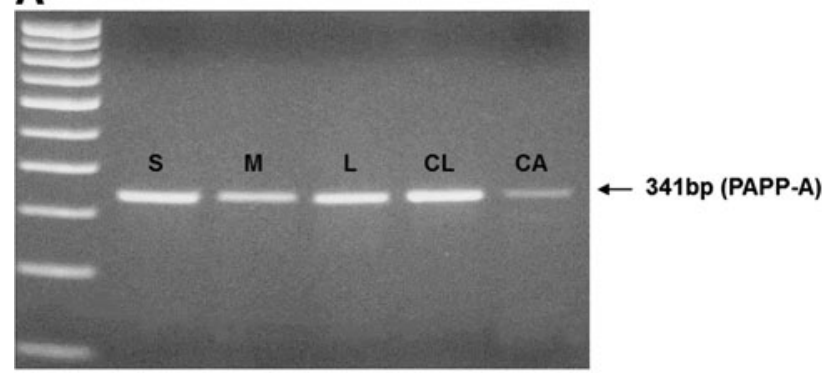

B
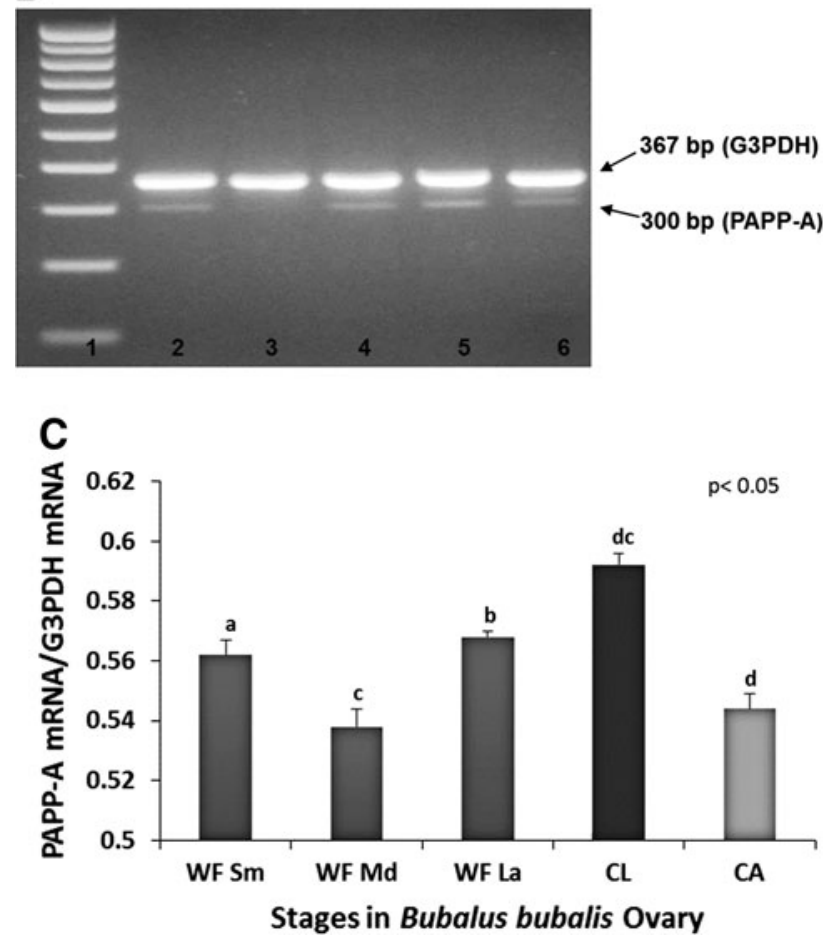

Fig. 1 A-C Expression of PAPP-A in Bubalus bubalus Ovary: PCR was carried out in $1.5 \mathrm{mM} \mathrm{MgCl} \mathrm{M}_{2}$ concentration at annealing temperature of $60{ }^{\circ} \mathrm{C}$ for 30 cycles without (A) or with (B) control gene $(\mathrm{G} 3 \mathrm{PDH})$ as shown in the figures. Lane 1 represents $100 \mathrm{bp}$ ladder. The control gene (G3PDH, $367 \mathrm{bp}$ ) bands showed consistent expression. Moderate PAPP-A expression was observed in small (S/ WF Sm) whole follicles (lane 2) and large (L/WF La) whole follicles (lane 4). In medium (M/WF Md) sized follicles, PAPP-A mRNA expression was down regulated (lane 3). Lane 5 represents highly up regulated PAPP-A mRNA expression in corpus luteum $(C L)$. Lane 6 represents low expression of PAPP-A mRNA in corpus albicans $(C A)$

represents the quantitative analysis of PAPP-A mRNA expression.

Expression of PAPP-A mRNA in granulosa cells isolated from different sized follicles has been shown in Fig. 2a with PAPP-A primers (first design) and Fig. $2 \mathrm{~b}$ with PAPP-A primers (second design). In both set of experiment, the expression pattern of PAPP-A gene expression was found to be consistent (Fig. 2c).
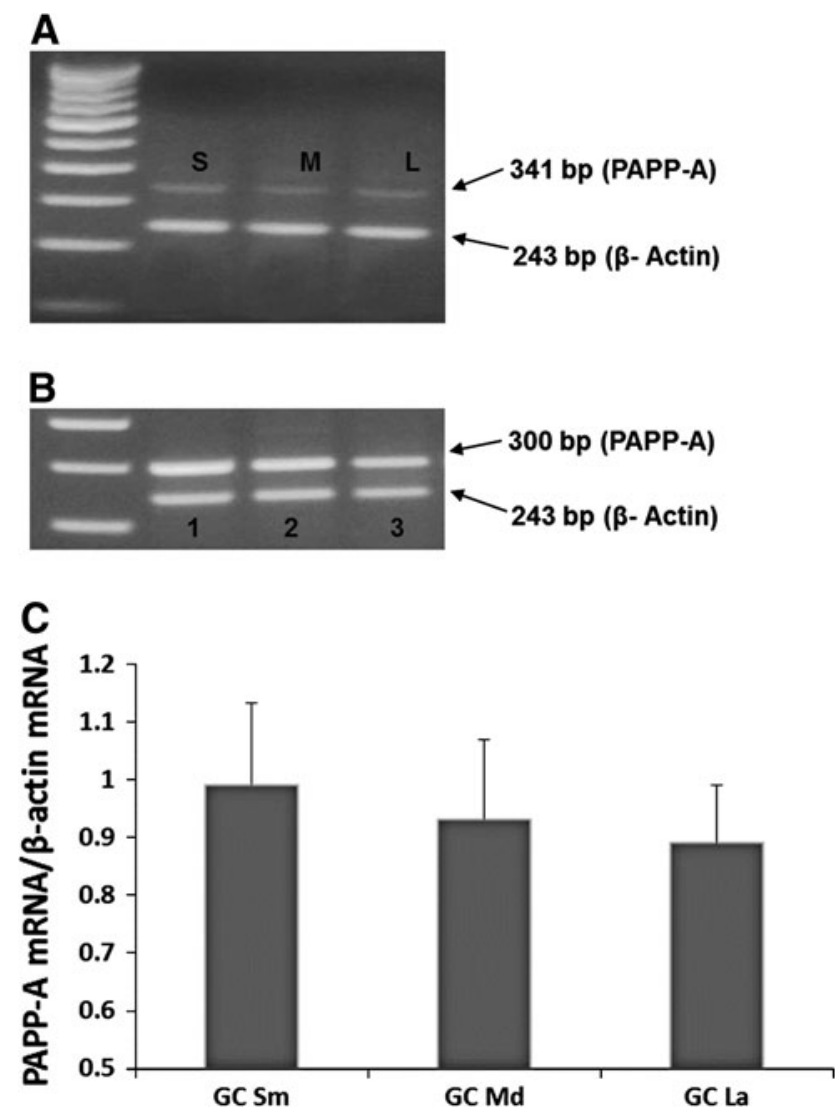

Fig. 2 A-C Expression of PAPP-A mRNA in granulosa cells isolated from different follicles. PCR was carried out in $1.5 \mathrm{mM}$ $\mathrm{MgCl}_{2}$ concentration at annealing temperature of $60{ }^{\circ} \mathrm{C}$ for 30 cycles with control gene ( $\beta$-actin, $243 \mathrm{bp}$ ) as shown in the figures. Lane 1 represents 100 bp DNA ladder. Lanes 2, 3, and 4 represent the moderate expression of PAPP-A mRNA (341 and $300 \mathrm{bp}$ with different set of primers) in granulosa cells of small (S/GC Sm), medium (M/GC Md), and large (L/GC La) follicles, respectively. A gradual decrease, though non-significant, in transcript levels was seen from small to large follicles

\section{Effect of FSH on PAPP-A mRNA Expression}

To assess whether PAPP-A mRNA are hormonally regulated, primary culture of buffalo granulosa cells were treated with ovine FSH (NIDDK-oFSH-17) at concentrations of 5 and $100 \mathrm{ng} / \mathrm{ml}$ for $24 \mathrm{~h}$ and RNA were isolated as described earlier. As shown in Fig. 3a, b, PAPP-A mRNA expression was found to be enhanced by both the concentration of FSH (5 ng/ml, lane 3; $100 \mathrm{ng} / \mathrm{ml}$, lane 4), as compared to control (lane 2). The stimulatory effect of FSH on PAPP-A expression has been found to be significant $(P<0.05)$.

Buffalo (Bubalus bubalis) PAPP-A Sequence

The primers set designed could amplify a maximum of 341 bp PAPP-A fragment. Custom sequencing of purified 

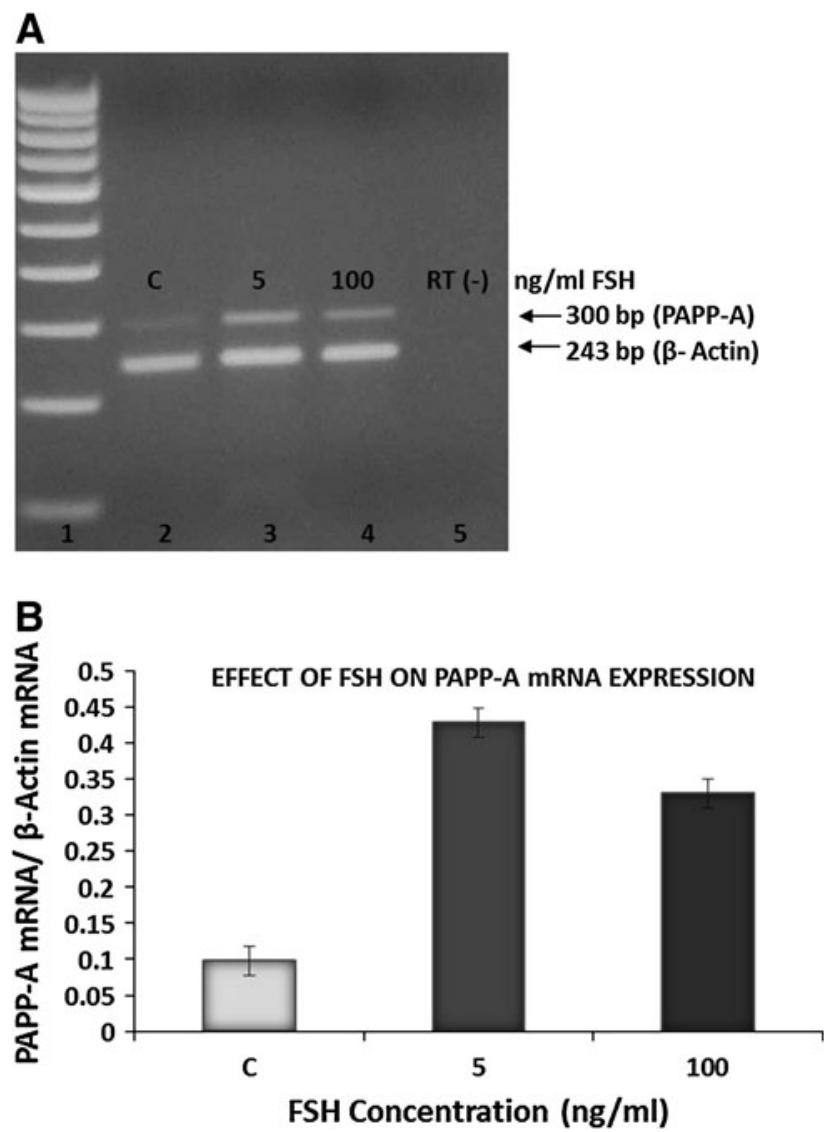

Fig. 3 A, B Effect of FSH treatment on PAPP-A gene expression in cultured granulosa cells. A Granulosa cells treated with different concentrations of FSH $(5 \mathrm{ng} / \mathrm{ml}$, lane $3 ; 100 \mathrm{ng} / \mathrm{ml}$, lane 4$)$ for $24 \mathrm{~h}$ showed an increased expression of PAPP-A mRNA as compared to control (c) (lane 2). Lane 1 represents $100 \mathrm{bp}$ DNA ladder. B Representative bar diagram showing the effect of FSH treatment on PAPP-A gene expression in cultured granulosa cells. Each value is the mean \pm standard error of three experiments

PCR products/amplicons confirmed this. The sequence was submitted to NCBI GenBank with the accession number (DQ079591). A BLAST search for this sequence in NCBI confirmed its relatedness/similarity with other mammalian and vertebrate PAPP-A sequences. Sequences of buffalo partial cDNA of PAPP-A, the deduced amino acid sequence, and potential phosphorylation sites have been shown in Fig. 4. Analysis of the obtained sequence showed that the $341 \mathrm{bp}$ transcript originates partly from exon 4 (position 1-106) to exon 5 (position 107-299) and exon 6 in part (position 300-341). ORF of Buffalo PAPP-A cDNA, starting with number 1 on the direct strand, extends from base 1 to base 339 and encodes 113 amino acid peptide of $12.61 \mathrm{kDa}$ molecular weight corresponding to part of proteolytic domain and central domain in the human PAPP-A protein. A total of 6 cysteines exist with a possibility of cysteines at positions $8,18,39$, and 53 to form the disulfide bond. Phosphorylation sites predicted are
Serine (position 33 and 104- Casein kinase II phosphorylation site, 65-protein kinase $\mathrm{C}$ phosphorylation site), Threonine (positions 26 and 81), and Tryptophan (position 28). PAPP-A is most likely not O-glycosylated, as $\mathrm{N}$-acetyl galactosamine was found to be absent from the isolated human PAPP-A subunit [38]. In silico analysis of 113 amino acid bubaline PAPP-A also did not reveal any potential O-glycosylation site. As shown in Fig. 6, 15th amino acid position (NDTC) may be the potential site for N-glycosylation with Asn-Xaa-Ser/Thr pattern. Potential sites for glycation of $\varepsilon$ amino groups of lysines are at amino acid positions 4 and 67. Similarly, positions 8 and 109 in the 113 amino acid bubaline PAPP-A sequence were found to be predicted as potential palmitoylation locations. Prediction of secondary structure by PSIPRED has revealed two $\alpha$-helices and two $\beta$-strands within the deduced 113 amino acid residues (Fig. 6). Sequence analysis using NetNES 1.1 server also revealed that buffalo PAPP-A sequence contains a putative leucine-rich NES as MHCYLDL residues with two leucines and well within the characteristic LXXXLXL pattern, where L may be any of $\mathrm{L}, \mathrm{I}, \mathrm{V}, \mathrm{F}$, and $\mathrm{M}$ amino acids.

\section{Comparison with Other Reported PAPP-A Sequences of Different Vertebrates}

As shown in Fig. 5, comparison of sequence of amplified partial PAPP-A cDNA (341 bp; GenBank accession no. DQ079591) from the buffalo ovary, with corresponding reported cDNA sequences of the same regions of cattle (XM_613511), sheep (AF421140), and horse (XM_0014 87931) have revealed a homology of 96,94 , and $93 \%$, respectively. Pig (XM_001926753), rabbit (XM_002720 482), and giant panda (XM_002915787) nucleotide sequences showed $90 \%$ identities. Mouse (NM_021362), rat (NM_001107939), human (X68280), rhesus monkey (XM_001095160), and chimpanzee nucleotide sequences illustrated 87-89\% homologies. Similarly, the deduced amino acid sequence (AAY86495.1) from buffalo PAPP-A partial cDNA sequence revealed a homology of 97, 96, 94, 93, and $88 \%$ with cattle, sheep, human, rat, and horse sequences, respectively (Fig. 6). Pig, rabbit, mouse, chimpanzee, giant panda, rhesus monkey,and white cheeked gabbon peptide sequences showed $95 \%$ homology. The buffalo peptide sequence also revealed $91,90,86,85,83,79$, 77,70 , and $65 \%$ homology with corresponding sequences of Sumatran orangutan, common marmoset, gray short tailed opossum, chicken, zebra finch, Carolina anole, western clawed frog, Arctic char fish, and Zebra fish, respectively. In comparing the homology at nucleotide level, buffalo PAPPA sequence had the highest homology of $96 \%$ for bovine sequences and lowest homology of $87 \%$ was for rat and 


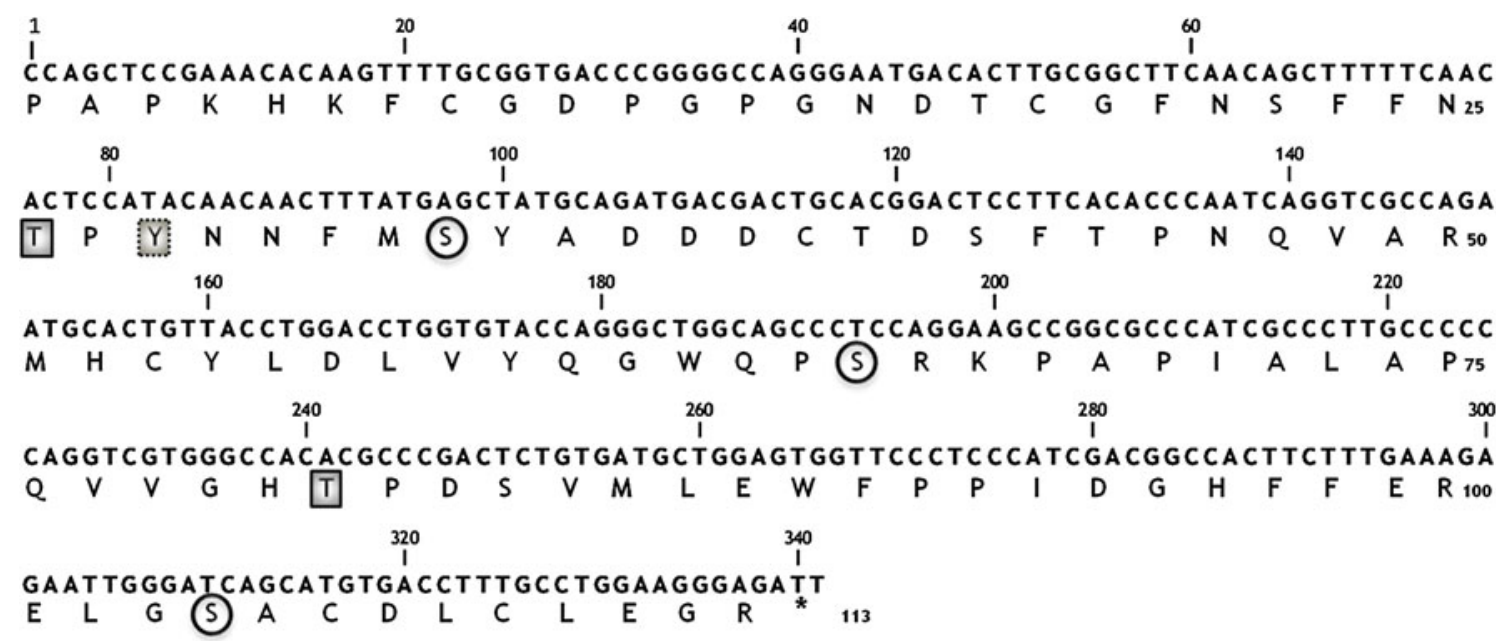

Fig. 4 cDNA Nucleotide sequence and corresponding deduced amino acid sequence of Bubalus bubalis PAPP-A: Sequence of amplified partial PAPP-A cDNA (341 bp) (GenBank accession no. DQ079591) with deduced 113 amino acid sequence is shown here. The putative phosphorylation sites are Serine (position 33 and 104-
Casein kinase II phosphorylation site, 65-protein kinase C phosphorylation site), Threonine (position 26 and 81), and Tryptophan (position 28). The Serine residues are shown as circles, Threonine as solid rectangles, and tryptophan as dotted rectangles. The position of * indicates the end of open reading frame mouse sequences among mammals. At the amino acid sequence level, the buffalo PAPP-A sequence had $97 \%$ homology with cattle (highest) and $86 \%$ with gray short tailed opossum (lowest) among mammals. Zebra fish showed only $65 \%$ homology.

Comparison and alignment of deduced amino acid sequences revealed a consensus sequence characteristic of PAPP-A (pappalysin-1). A unique amino acid sequence, NFM (NXM) was found to be conserved among different species and interestingly, this corresponds to conserved Met-turn of PAPP-A. The linear distance between putative elongated zinc-binding consensus sequence HEXXHX XGXXH of other species' PAPP-A sequences and Metturn of bubaline PAPP-A amino acid sequence was found to be 63 , a characteristic of pappalysins of metzincin family of metalloproteases. The family-specific residue Asn $(\mathrm{N})$ was also found exactly two residues before the Met (M) of the Met-turn. Cysteine-glutamine repeats at alignment positions 8-9 and 18-19 were found to be conserved across all the mammals compared. A putative leucine-rich NES signal with LXXXLXL pattern is also found to be conserved in all the mammals as shown in Fig. 6. Superimposing the NES signal sequence on the consensus sequence of PAPP-A together with its pattern of hydrophobic residues and charged or polar residues clearly reveals its amphipathic $\alpha$ helical secondary structure. Putative NLSs in PAPP-A were also mapped using cNLS mapper [25] at lower score of 2/3 and bipartite NLS was predicted between amino acid positions 1 and 33, attributing speculation of shuttling of protein between nucleus and cytoplasm or localized to cytoplasm.

\section{Molecular Phylogenetic Analysis}

To visualize the phylogenetic relationship of the deduced amino acid sequence of buffalo PAPP-A gene with those of other sequences known in other mammalian species, we analyzed 15 sequences: 1 of buffalo, 3 of other ruminants (cattle and sheep), 2 of pig, 2 of horses, 1 of giant panda, 2 of rodents (rat and mouse), 3 of primates (human, chimpanzee, and rhesus monkey), and 1 of rabbit. Based on multiple sequence alignment of 113 amino acid buffalo PAPP-A sequence with other PAPP-A sequences of these selected species, the phylogenetic tree was constructed. The result is shown in Fig. 7. Closely related mammalian species were grouped in different clades or taxonomical orders. The phylogenetic analysis showed 4 clades: A, B, C, and D. Clade A includes three embranchments: Indian water buffalo/cattle embranchment, sheep embranchment, and pig embranchment - all being members of cetartiodactyla. The B clade includes the horse (perissodactyla) and giant panda (carnivora) embranchment. The $\mathrm{C}$ clade includes members of rodentia and the mouse/rat embranchment. The $\mathrm{D}$ clade of primates comprised the human/chimpanzee, rhesus monkey, and rabbit embranchments. Finally, there were distinct clades of cetartiodactyla, perissodactyla, carnivore, rodentia, and primates. These data indicate a greater phylogenetic affinity among Indian water buffalo, cattle, and sheep compared to that found with horse, carnivores, and primates. It is of interest to determine whether either of the clades Euungulata (Perissodactyla + Cetartiodactyla) or Zooamata (Perissodactyla + Carnivora + Pholidota) is valid [51] The phylogenetic tree here, however, unexpectedly 


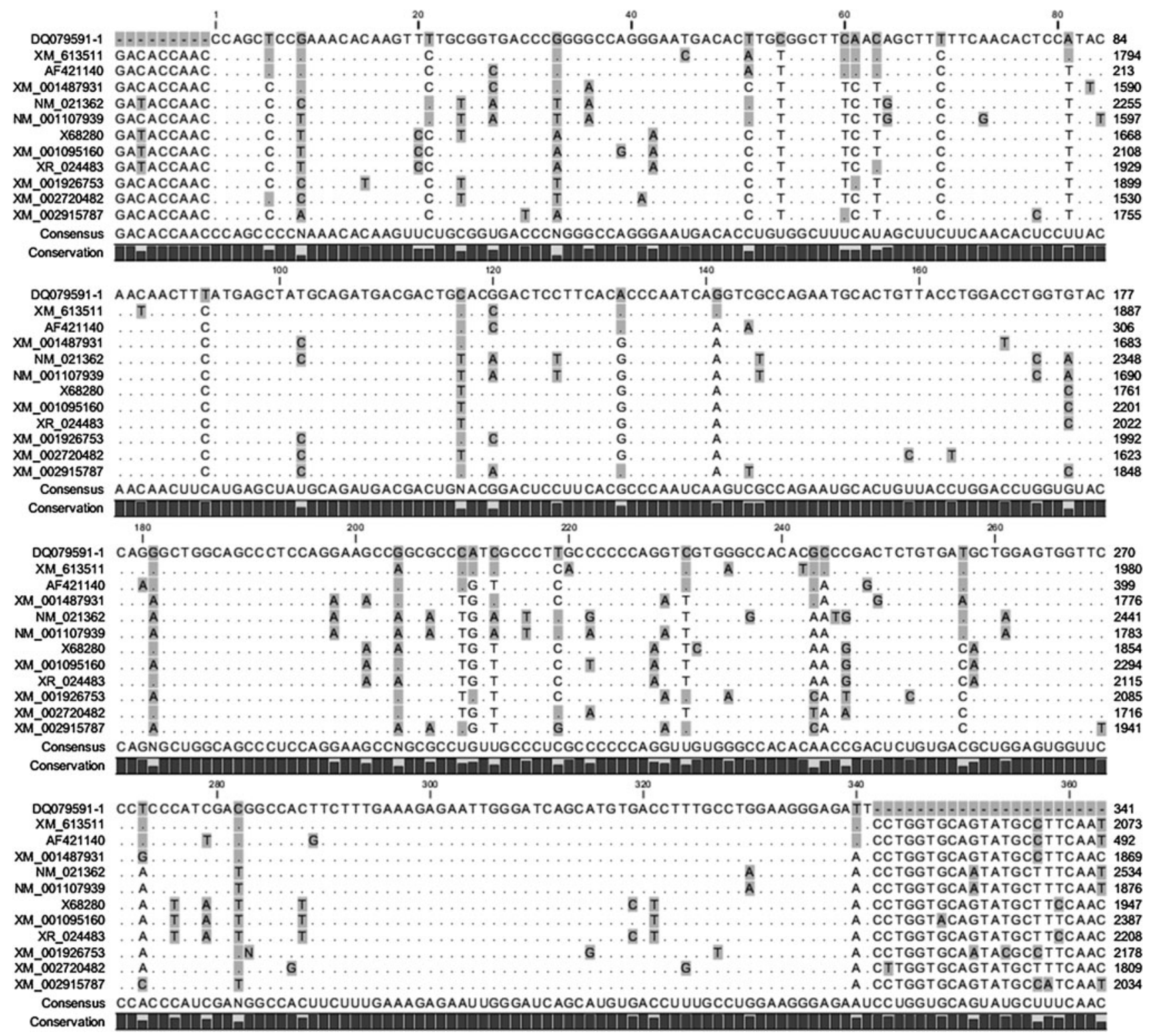

Fig. 5 Alignment of nucleotide sequences of the Bubalus bubalis PAPP-A with those of other species: the sequences for alignment were taken from 12 mammalian PAPP-A sequences [cattle (XM_613511), sheep (AF421140), horse (XM_001487931), pig (XM_001926753), rabbit (XM_002720482), giant panda (XM_002915787), mouse (NM_021362), rat (NM_001107939), human (X68280), rhesus

supported for the Zooamata clade comprising of perissodactyla and carnivora. All the eutherian orders make for monophyletic clades typically characterized by shared derived characteristics (synapomorphies).

Putative Localization of PAPP-A on Bubaline Chromosome

BLAST searches (CoGe BLAST and NCBI BLAST) using the 341 nucleotide buffalo PAPP-A sequence against all monkey (XM_001095160), and chimpanzee (XR_024483)] including Indian water buffalo (DQ079591). Dots indicate the identical nucleotides as Indian water buffalo PAPP-A sequence and dash (-) missing nucleotides/gaps. The shaded nucleotides are the nucleotides different from the consensus sequence

the available genome databases of animals related it to PAPP-A and as located in chromosomes 1 (Sus scrofa), 25 (Equus caballus), 9 (location 9q33.2; Homo sapiens), 4 (location $432.2 \mathrm{cM}$; Mus musculus), 5 (location 5q24; Rattus norvegicus), 11 (Canis lupus familiaris), 17 (Gallus gallus), 15 (Macaca mulatta), 9 (Pan troglodytes), and 8 (NC_007306.4; Bos taurus). This option was not available for Bubalus bubalis genome in any of the databases available. However, in construction of preliminary and first generation whole genome radiation hybrid map of Bubalus 


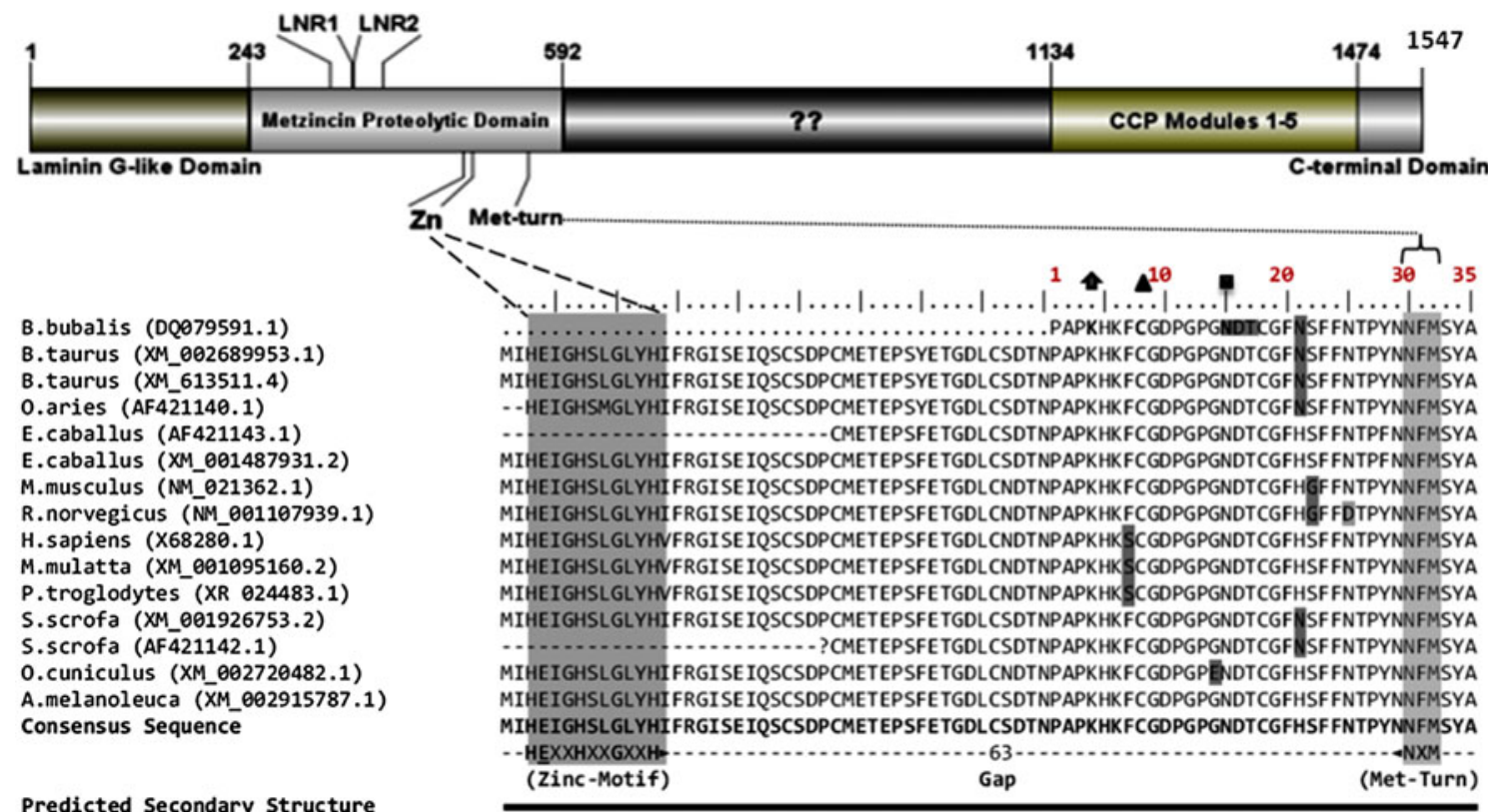

Predicted Secondary Structure

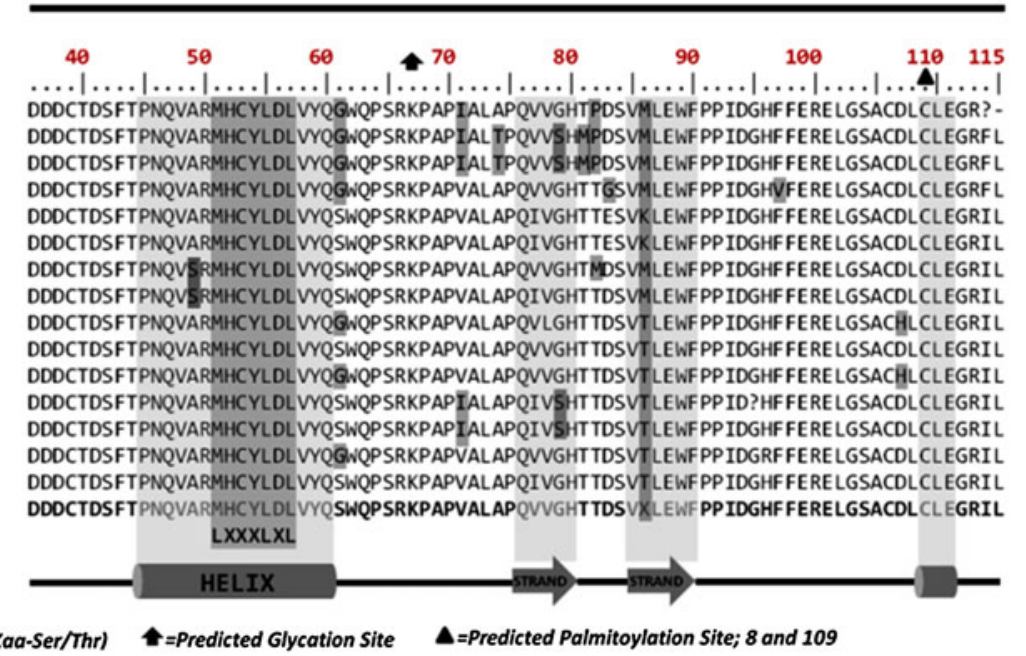

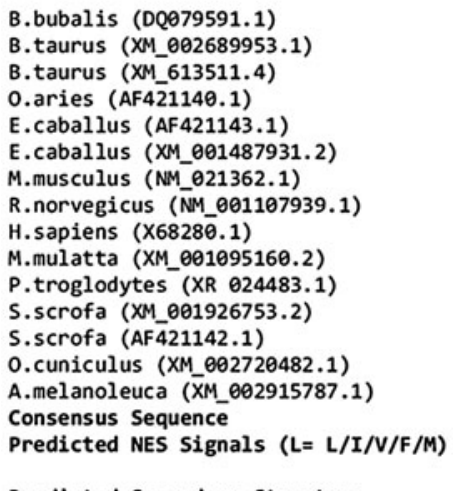

Fig. 6 Comparison of putative amino acid sequence of the Bubalus bubalis PAPP-A with cattle, sheep, horse, mouse, rat, human, rhesus monkey, chimpanzee, pig, rabbit, and giant panda: The aligned sequences were compared with the 1,547 amino acid human PAPP-A showing the domain structure. Accession numbers of sequences compared is shown in the figure. The consensus sequence illustrates clearly the zinc motif with residues HEXXHXXGXXH as shaded region. Conserved NFM (NXM) amino acid residues of met-turn are

bubalis chromosomes using cattle markers it was revealed that Bos taurus chromosome 8 (BTA8) equals Bubalus bubalis chromosome $3 \mathrm{q}$ (BBU3q) [3, 4]. This gives a logical and probable location of PAPP-A gene in the $\mathrm{Bu}$ balus bubalis chromosome $3 \mathrm{q}$ (BBU3q).

\section{Discussion}

In this study, we have identified and characterized the transcript of PAPP-A gene in Indian water buffalo also shaded. Other amino acid residues which show difference with consensus sequence are shown as shaded. The predicted secondary structure is also shown. Putative NES signals (LXXXLXL) are also shown in the figure well within the $\alpha$-helical secondary structure. The position of filled square indicates the potential N-glycosylation site (Asn-Xaa-Ser/Thr), upward arrow indicates putative glycation sites, and filled triangle indicates predicted palmitoylation sites

(Bubalus bubalis) ovary for the first time and the sequence analysis revealed that it share the characteristics of pappalysin-1 of metzincin family of metalloproteases. The spatial and temporal expression patterns, localization, and hormonal regulation of PAPP-A, in buffalo ovary was analyzed by sequence analysis and semi-quantitative RTPCR which is a highly sensitive and specific method useful for the detection of rare transcripts and are still appropriate for many purposes [2, 12, 15, 19, 46]. $\beta$-actin [18] and G3PDH were used as internal controls. It is now known that changes in intra-follicular IGF system provide a 


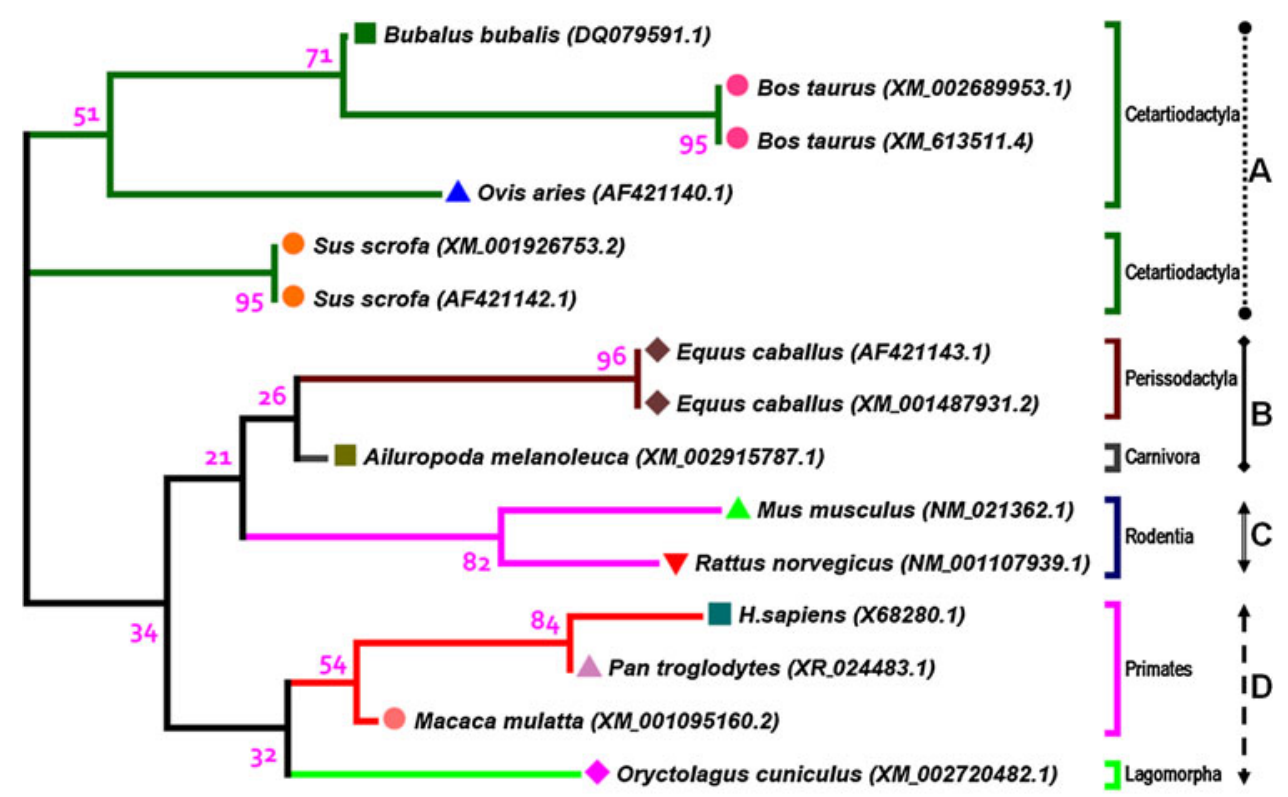

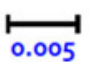

Fig. 7 Phylogenetic relationship of the peptide sequence of Indian water buffalo (Bubalus bubalis) PAPP-A with other 14 reported peptide/protein sequences of different mammals: Molecular phylogenetic analysis was performed from the data provided by the multiple sequence alignment patterns of amino acids. The sources of all the sequence data are represented in the phylogenetic tree. The

critical "fine tuning" of follicular regulation and is important for selection of a follicle from a cohort of similar sized follicles. Follicular selection may be the result of a progressive series of changes beginning with acquisition of PAPP-A, with concomitant decrease in IGFBPs and increase in free IGF, which synergizes with FSH to increase estradiol production. Thus, in mammalian ovary, the expression of PAPP-A relates to steroidogenic activity and follicular selection [17].

In this study, we detected expression of PAPP-A in different sized antral follicles, postovulatory structures (corpus luteum and corpus albicans), and granulosa cells isolated from follicles of different sizes. Little or no differences in levels of PAPP-A mRNA expression were found in the small and large sized whole follicles and granulosa cells isolated from different sized follicles. Similar observations were found in granulosa cells isolated from small and large healthy bovine and porcine follicles [34]. A higher transcriptional level of PAPP-A mRNA with distinct differences was detected in ovarian corpus luteum. In fact, the expression of PAPP-A mRNA was found to be highly up regulated (Fig. 1a, b, Lane 5 and Fig. 1c), whereas expression of IGFBP-5 mRNA was found to be down regulated (unpublished) in corpus luteum. Above observations have shown that buffalo corpus luteum has a strong message for IGFBP-5. Furthermore, there was phylogeny is an un-rooted tree recovered using the maximumlikelihood (ML) method based on 1,000 bootstrap replications and Jones-Taylor-Thornton (JTT) matrix-based model by the MEGA 5.0 program. Only bootstrap value greater than $>0 \%$ is shown on the branch. The clades are shown as $A, B, C$, and $D$

decrease in expression of mRNA encoding PAPP-A in corpus albicans (Fig. 1a, b, Lane 6 and Fig. 1c). The result implied that in buffalo corpus luteum, PAPP-A is highly expressed in early luteal phase, with a tendency to decrease thereafter. It has been found previously that IGF system played an important role especially for the development of the early CL by action on luteinization of granulosa-lutein cells and stimulation of oxytocin and progesterone production [44]. Increased level of IGFBPs as a result of decreased PAPP-A activity may lead to decreased levels of IGFs which, apart from other factors, may lead to decreased blood flow and progesterone level and increased apoptosis causing functional and structural luteolysis. In this study, a high expression of PAPP-A mRNA in the corpus luteum was found as observed for woman ovary by in situ hybridization [22]. Relatively low expression of PAPP-A mRNA has been observed in corpus albicans of buffalo ovary as compared to corpus luteum. These facts imply a role for PAPP-A as a marker of ovarian follicle selection and corpus luteum formation in Indian water buffalo. There could be two possibilities of lower transcriptional level of PAPP-A in medium sized follicles than that of large follicles. First, population of atretic follicles may be more in the pool of medium follicles. However, we have collected the follicles based on the criteria used by other workers detailed in "Materials and methods." 
Furthermore, we have also quantified Bcl-2 mRNA (not shown here) expression in pool of granulosa cells isolated from different sized follicles with no change in Bcl-2 mRNA expression. Second, stage-specific PAPP-A expression or other cells like theca cells may be contributing to decreased transcriptional level of PAPP-A.

Regulatory mechanism underlying the synergism exerted by FSH in stimulating PAPP-A gene expression (Fig. 3a, b) in differentiating granulosa cells has been elucidated. Many studies have shown that growth factors like GH, insulin, and IGF-I [1] and hormones like FSH [40] and LH [31] play an important role in intraovarian regulation of follicular development in a species-specific manner. In this study, it was found that treatment of cultured buffalo granulosa cells with FSH caused a marked increase in PAPP-A mRNA expression. FSH-induced PAPP-A message is in accordance with the similar observation found in cultured rat granulosa cells [33]. This study confirmed the stimulatory effect of FSH on PAPP-A mRNA expression in cultured buffalo granulosa cells.

Nucleotide sequence was determined by custom sequencing and amino acid sequences were deduced. Partial Indian water buffalo PAPP-A cDNA contains a coding region of $341 \mathrm{bp}$, corresponds to 113 amino acid sequence and spans from exon 4 to 6. Buffalo PAPP-A nucleotide sequence was found closer to ruminants (cattle and sheep) compared to the other mammalian species. Cattle and sheep nucleotide sequences showed 96-97\% identity, whereas distant relatives like rat and mouse showed only $87 \%$ identity with that of buffalo sequences. Deduced amino acid sequence from the $341 \mathrm{bp}$ ORF was found to be 113 residues long. Buffalo PAPP-A amino acid sequence had a $97 \%$ identity with cattle, $86 \%$ with opossum, and only $65 \%$ identity with Zebra fish. Several characteristics of PAPP-A (pappalysin) was evident on sequence analysis, comparison and alignment of nucleotide and deduced amino acid sequences. Tblast $\mathrm{N}$ and blastP searches have unearthed the unique and characteristic NFM (NXM) amino acid residues corresponding to conserved Met-turn of PAPP-A and found to be conserved among different species. The family-specific residue Asn (N) was also found exactly two residues before the Met (M) of the Metturn. The linear distance between putative elongated zincbinding consensus sequence HEXXHXXGXXH of other species' PAPP-A sequences and Met-turn of bubaline PAPP-A amino acid sequence was found to be 63 , a characteristic of pappalysins of metzincin family of metalloproteases. Domain database (CDD) search results also implied that bubaline PAPP-A belongs to Zinc-metzincin superfamily (zinc-dependent metalloprotease) and pappalysin-like subfamily. Actual alignment was detected with superfamily member cd04275 (ZnMc-pappalysin like). A total of 6 cysteines were found and conserved Cysteine- glutamine repeats at alignment positions $8-9$ and $18-19$ may have some functional role. The Buffalo PAPP-A amino acid sequence was predicted to have two $\alpha$-helices and two $\beta$-strands. A putative leucine-rich NES signal was also detected and its amphipathic $\alpha$-helical secondary structure was revealed. Potential sites for N-glycosylation with Asn-Xaa-Ser/Thr pattern were detected at 6th and 15th amino acid position. Palmitoylation and glycation sites were also located. Positions 26, 33, 65, 81, and 104 are potential phosphorylation sites. The probable location of PAPP-A in buffalo chromosome may be traced to chromosome 3q (BBU3q). Phylogenetic analyses also demonstrated distinct clades of cetartiodactyla, perissodactyla, carnivore, rodentia, and primates. A greater phylogenetic affinity was observed among Indian water buffalo, cattle, and sheep compared to that found with horse, carnivores, and primates. It is of interest to determine whether either of the clades Euungulata (Perissodactyla + Cetartiodactyla) or Zooamata (Perissodactyla + Carnivora + Pholidota) is valid. This was also a supporting information for Zooamata clade.

In conclusion, cDNA encoding the pregnancy-associated plasma protein-A (PAPP-A) was amplified and sequenced from the Indian water buffalo (Bubalus bubalis) ovary. The 341 bp buffalo PAPP-A cDNA encodes for 113 amino acid peptide sequence. Sequence analyses have clearly revealed that bubaline PAPP-A belongs to Zincmetzincin superfamily (zinc-dependent metalloprotease) and pappalysin-like subfamily. It also confirmed the stimulatory effect of FSH on PAPP-A mRNA expression. Further exploration of expression patterns and better understanding of "follicular microenvironment" may pave ways for strategies concerned with ovarian function, fertility, and productivity in females.

Acknowledgments Authors thank Dr. Parlow (NIDDK, USA) for the gift of ovine FSH -17. Authors are also very grateful to Director NDRI, Karnal for providing necessary facilities for this study. The financial assistance of NDRI-JRF to Varij Nayan is thankfully acknowledged.

\section{References}

1. Adashi EY, Resnick CE, D'Ercole AJ, Svoboda ME, Van Wyk JJ (1985) Insulin-like growth factors as intraovarian regulators of granulosa cell growth and function. Endocr Rev 6(3):400-420

2. Ali SA, Sarto I, Steinkasserer A (1997) Production for PCR mimics for any semiquantitative PCR application. Biotechniques 22(6):1060-1062

3. Amaral ME, Grant JR, Riggs PK, Stafuzza NB, Filho EA, Goldammer T, Weikard R, Brunner RM, Kochan KJ, Greco AJ, Jeong J, Cai Z, Lin G, Prasad A, Kumar S, Saradhi GP, Mathew B, Kumar MA, Miziara MN, Mariani P, Caetano AR, Galvão SR, Tantia MS, Vijh RK, Mishra B, Kumar ST, Pelai VA, Santana AM, Fornitano LC, Jones BC, Tonhati H, Moore S, Stothard P, 
Womack JE (2008) A first generation whole genome RH map of the river buffalo with comparison to domestic cattle. BMC Genomics 9:631

4. Amaral ME, Owens KE, Elliott JS, Fickey C, Schäffer AA, Agarwala R, Womack JE (2007) Construction of a river buffalo (Bubalus bubalis) whole-genome radiation hybrid panel and preliminary RH mapping of chromosomes 3 and 10. Anim Genet 38(3):311-314

5. Bayes-Genis A, Schwartz RS, Lewis DA, Overgaard MT, Christiansen M, Oxvig C, Ashai K, Holmes DR Jr, Conover CA (2001) Insulin-like growth factor binding protein-4 protease produced by smooth muscle cells increases in the coronary artery after angioplasty. Arterioscler Thromb Vasc Biol 21(3):335-341

6. Blom N, Gammeltoft S, Brunak S (1999) Sequence and structurebased prediction of eukaryotic protein phosphorylation sites. J Mol Biol 294(5):1351-1362

7. Bode W, Gomis-Rüth FX, Stöckler W (1993) Astacins, serralysins, snake venom and matrix metalloproteinases exhibit zincbinding environments (HEXXHXXGXXH and Met-turn) and topologies and should be grouped into a common family, the 'metzincins'. FEBS Lett 331(1-2):134-140

8. Boldt HB, Conover CA (2007) Pregnancy-associated plasma protein-A (PAPP-A): a local regulator of IGF bioavailability through cleavage of IGFBPs. Growth Horm IGF Res 17(1):10-18

9. Boldt HB, Overgaard MT, Laursen LS, Weyer K, Sottrup-Jensen L, Oxvig C (2001) Mutational analysis of the proteolytic domain of pregnancy-associated plasma protein-A (PAPP-A): classification as a metzincin. Biochem J 358(Pt2):359-367

10. Bryson K, McGuffin LJ, Marsden RL, Ward JJ, Sodhi JS, Jones DT (2005) Protein structure prediction servers at University College London. Nucleic Acids Res 33:W36-W38

11. Byun D, Mohan S, Yoo M, Sexton C, Baylink DJ, Qin X (2001) Pregnancy-associated plasma protein-A accounts for the insulin like growth factor (IGF)-binding protein-4 (IGFBP-4) proteolytic activity in human pregnancy serum and enhances the mitogenic activity of IGF by degrading IGFBP-4 in vitro. J Clin Endocrinol Metab 86(2):847-854

12. Carding SR, Lu D, Bottomly K (1992) A polymerase chain reaction assay for detection and quantitation of cytokine gene expression in small number of cells. J Immunol Methods 151(1-2):277-287

13. Conover CA, Bale LK, Overgaard MT, Johnstone EW, Laursen UH, Füchtbauer EM, Oxvig C, van Deursen J (2004) Metalloproteinase pregnancy-associated plasma protein $\mathrm{A}$ is a critical growth regulatory factor during fetal development. Development 131(5):1187-1194

14. Conover CA, Oxvig C, Overgaard MT, Christiansen M, Giudice LC (1999) Evidence that the insulin-like growth factor binding protein-4 protease in human ovarian follicular fluid is pregnancy associated plasma protein-A. J Clin Endocrinol Metab 84(12): 4742-4745

15. Erlich HA (1989) PCR technology: principles and applications for DNA amplification. Stockton Press, New York

16. Ferrè F, Clote $\mathrm{P}$ (2005) DiANNA: a web server for disulfide connectivity prediction. Nucleic Acids Res 33:W230-W232

17. Fortune JE, Rivera GM, Yang MY (2004) Follicular development: the role of the follicular microenvironment in selection of the dominant follicle. Anim Reprod Sci 82-83:109-126

18. Foss DL, Baarsch MJ, Murtaugh MP (1998) Regulation of hypoxanthine phosphoribosyltransferase, glyceraldehydes-3phosphate dehydrogenase and beta-actin mRNA expression in porcine immune cells and tissues. Anim Biotech 9(1):67-78

19. Freeman WM, Walker SJ, Vrana KE (1999) Quantitative RTPCR: pitfalls and potential. Biotechniques 26(1):112-125

20. Giudice LC, Conover CA, Bale L, Faessen GH, Ilg K, Sun I, Imani B, Suen LF, Irwin JC, Christiansen M, Overgaard MT,
Oxvig C (2002) Identification and regulation of the IGFBP-4 protease and its physiological inhibitor in human trophoblasts and endometrial stroma: evidence for paracrine regulation of IGF-II bioavailability in the placental bed during human implantation. J Clin Endocrinol Metab 87(5):2359-2366

21. Hirshfield AN (1991) Development of follicles in the mammalian ovary. Int Rev Cytol 124:43-101

22. Hourvitz A, Widger AE, Filho FL, Chang RJ, Adashi EY, Erickson GF (2000) Pregnancy-associated plasma protein-A gene expression in human ovaries is restricted to healthy follicles and corpora lutea. J Clin Endocrinol Metab 85(12):4916-4920

23. Johansen MB, Kiemer L, Brunak S (2006) Analysis and prediction of mammalian protein glycation. Glycobiology 16(9):844853

24. Jones DT, Taylor WR, Thornton JM (1992) The rapid generation of mutation data matrices from protein sequences. Comput Appl Biosci 8(3):275-282

25. Kosugi S, Hasebe M, Tomita M, Yanagawa H (2009) Systematic identification of cell cycle-dependent yeast nucleocytoplasmic shuttling proteins by prediction of composite motifs. Proc Natl Acad Sci USA 106(25):10171-10176

26. Kristensen T, Oxvig C, Sand O, Møller NP, Sottrup-Jensen L (1994) Amino acid sequence of human pregnancy-associated plasma protein-A derived from cloned cDNA. Biochemistry 33(6):1592-1598

27. la Cour T, Kiemer L, Mølgaard A, Gupta R, Skriver K, Brunak S (2004) Analysis and prediction of leucine-rich nuclear export signals. Protein Eng Des Sel 17(6):527-536

28. Lawrence JB, Oxvig C, Overgaard MT, Sottrup-Jensen L, Gleich GJ, Hays LG, Yates JR 3rd, Conover CA (1999) The insulin-like growth factor (IGF)-dependent IGF binding protein-4 protease secreted by human fibroblasts is pregnancy associated plasma protein-A. Proc Natl Acad Sci USA 96(6):3149-3153

29. Lin TM, Galbert SP, Kiefer D, Spellacy WN, Gall S (1974) Characterization of four human pregnancy-associated plasma proteins. Am J Obstet Gynecol 118(2):223-236

30. Liu XJ, Malkowski M, Guo Y, Erickson GF, Shimasaki S, Ling N (1993) Development of specific antibodies to rat insulin-like growth factor-binding proteins (IGFBP-2 to-6): analysis of IGFBP production by rat granulosa cells. Endocrinol 132(3):1176-1183

31. Luo L, Chen H, Stocco DM, Zirkin BR (1998) Leydig cell protein synthesis and steroidogenesis in response to acute stimulation by luteinizing hormone in rats. Biol Reprod 59(2):263-270

32. Malhotra N, Singh D, Sharma MK (2007) Cloning, expression and hormonal regulation of steroidogenic acute regulatory protein gene in buffalo ovary. Asian-Aust J Anim Sci 20(2):184-193

33. Matsui M, Sonntag B, Hwang SS, Byerly T, Hourvitz A, Adashi EY, Shimasaki S, Erickson GF (2004) Pregnancy-associated plasma protein-A production in rat granulosa cells: stimulation by follicle-stimulating hormone and inhibition by the oocyte-derived bone morphogenetic protein-15. Endocrinol 145(8):3686-3695

34. Mazerbourg S, Overgaard MT, Oxvig C, Christiansen M, Conover CA, Laurendeau I, Vidaud M, Tosser-Klopp G, Zapf J, Monget P (2001) Pregnancy-associated plasma protein-A (PAPPA) in ovine, bovine, porcine and equine ovarian follicles: involvement in IGF binding protein-4 proteolytic degradation and mRNA expression during follicular development. Endocrinol 142(12):5243-5253

35. Mazerbourg S, Zapf J, Bar RS, Brigstock DR, Monget P (2000) Insulin-like growth factor (IGF)-binding protein-4 proteolytic degradation in bovine, equine, and porcine preovulatory follicles: regulation by IGFs and heparin-binding domain-containing peptides. Biol Reprod 63(2):390-400

36. Ohnishi J, Ohnishi E, Shibuya H, Takahashi T (2005) Functions for proteinases in the ovulatory process. Biochim Biophys Acta 1751(1):95-109 
37. Overgaard MT, Haaning J, Boldt HB, Olsen IM, Laursen LS, Christiansen M, Gleich GJ, Sottrup-Jensen L, Conover CA, Oxvig C (2000) Expression of recombinant human pregnancyassociated plasma protein-A and identification of the proform of eosinophil major basic protein as its physiological inhibitor. J Biol Chem 275(40):31128-31133

38. Oxvig C, Sand O, Kristensen T, Kristensen L, Sottrup-Jensen L (1994) Isolation and characterization of circulating complex between human pregnancy-associated plasma protein-A and proform of eosinophil major basic protein. Biochim Biophys Acta 1201(3):415-423

39. Pederson T (1970) Follicle kinetics in the ovary of the cyclic mouse. Acta Endocrinol 64(2):304-323

40. Pescador N, Houde A, Stocco DM, Murphy BD (1997) Folliclestimulating hormone and intracellular second messengers regulate steroidogenic acute regulatory protein messenger ribonucleic acid in luteinized porcine granulosa cells. Biol Reprod 57(3):660-668

41. Ren J, Wen L, Gao X, Jin C, Xue Y, Yao X (2008) CSS-Palm 2.0: an updated software for palmitoylation sites prediction. Protein Eng Des Sel 21(11):639-644

42. Robker RL, Richards JS (1998) Hormonal control of the cell cycle in ovarian cells: proliferation versus differentiation. Biol Reprod 59(3):476-482

43. Sambrook J, Fritsch EF, Maniatis T (1989) Molecular cloning: a laboratory manual, 2nd edn. Cold Spring Harbor Laboratory Press, Cold Spring Harbor, New York

44. Schams D (1987) Luteal peptides and intercellular communication. J Reprod Fertil Suppl 34:87-99
45. Søe R, Overgaard MT, Thomsen AR, Laursen LS, Olsen IM, Sottrup-Jensen L, Haaning J, Giudice LC, Conover CA, Oxvig C (2002) Expression of recombinant murine pregnancy-associated plasma protein-A (PAPP-A) and a novel variant (PAPP-Ai) with differential proteolytic activity. Eur J Biochem 269(8): 2247-2256

46. Souazé F, Ntodou-Thomé A, Tran CY, Rostène W, Forgez P (1996) Quantitative RT-PCR: limits and accuracy. Biotechniques 21(2):280-285

47. Soumano K, Price CA (1997) Ovarian follicular steroidogenic acute regulatory protein, low-density lipoprotein receptor, and cytochrome P450 side-chain cleavage messenger ribonucleic acids in cattle undergoing superovulation. Biol Reprod 56(2): $516-522$

48. Stöcker W, Grams F, Baumann U, Reinemer P, Gomis-Rüth FX, McKay DB, Bode W (1995) The metzincins-topological and sequential relations between the astacins, adamalysins, serralysins, and matrixins (collagenases) define a superfamily of zincpeptidases. Protein Sci 4(5):823-840

49. Tamura K, Dudley J, Nei M, Kumar S (2007) MEGA4: molecular evolutionary genetics analysis (MEGA) software version 4.0. Mol Biol Evol 24(8):1596-1599

50. Vinze M, Sharma MK, Singh D (2004) Effect of follicular fluid proteins and gonadotropins on progesterone secretion by buffalo granulosa cells in vitro. Asian-Aust J Anim Sci 17(11): 1496-1500

51. Waddell PJ, Kishino H, Ota R (2001) A phylogenetic foundation for comparative mammalian genomics. Genome Inform 12: $141-154$ 